\title{
Mapping of advanced practice nursing actions in the Family Health Strategy
}

\author{
Mapeamento de ações de práticas avançadas de enfermagem na Estratégia Saúde da Família \\ Mapeo de acciones de Prácticas Avanzadas de Enfermería en Estrategia Salud de la Familia
}

\section{Emerson Willian Santos de Almeida' ORCID: 0000-0002-6846-021X}

Simone de Godoy' ORCID: 0000-0003-0020-7645

Ítalo Rodolfo Silva" ORCID: 0000-0002-2882-1877

Orlene Veloso Dias"' ORCID: 0000-0002-9017-7875

Leila Maria Marchi-Alves' ORCID: 0000-0001-9374-8074

Isabel Amélia Costa Mendes' ORCID: 0000-0002-0704-4319

'Universidade de São Paulo. Ribeirão Preto, São Paulo, Brazil. "Universidade Federal de Rio de Janeiro. Macaé, Rio de Janeiro, Brazil. "'Universidade Estadual de Montes Claros. Montes Claros, Minas Gerais, Brazil.

How to cite this article:

Almeida EWS, Godoy S, Silva IR, Dias OV, Marchi-Alves LM, Mendes IAC. Mapping of advanced practice nursing actions in the Family Health Strategy. Rev Bras Enferm. 2021;74(Suppl 6):e20210228. https://doi.org/10.1590/0034-7167-2021-0228

Corresponding author: Isabel Amélia Costa Mendes

E-mail: iamendes@usp.br

EDITOR IN CHIEF: Dulce Barbosa ASSOCIATE EDITOR: Álvaro Sousa

Submission: $03-30-2021$

Approval: 05-18-2021

\section{ABSTRACT}

Objectives: to map advanced practice nursing actions implemented in the Family Health Strategy context. Methods: cross-sectional exploratory study carried out with Family Health Strategy nurses. Data obtained in the mapping were compared to the characteristics that define advanced practice nurses and are adopted internationally by using a checklist based on the International Council of Nurses Guidelines. Results: the mapping allowed to identify advanced practice nursing actions, such as advanced assessment, judgement, decisionmaking, and diagnostic reasoning skills and authority to diagnose and prescribe medications, diagnostic testing, and therapeutic treatments. However, evidence found in the educational preparation domain indicated evident fragility, expressed as the low percentage of nurses credentialed with a professional master's degree. Conclusions: the present study showed that nurses in the Family Health Strategy carry out advanced practice nursing actions without the professional master's degree recommended for credentialing, with pertinent legislation, which requires initiatives to be taken by nursing leaders to overcome this deficiency. Descriptors: Advanced Practice Nursing; Primary Health Care; Family Health Strategy; Nursing; Nursing Education.

\section{RESUMO}

Objetivos: mapear ações de Práticas Avançadas de Enfermagem implementadas no contexto da Estratégia Saúde da Família. Métodos: estudo transversal, exploratório, realizado com enfermeiros que trabalham na Estratégia Saúde da Família. Os dados obtidos no mapeamento foram comparados às características definidoras do Enfermeiro de Prática Avançada adotadas internacionalmente, por meio de checklist elaborado tendo como referência as diretrizes do International Council of Nurses. Resultados: o mapeamento permitiu identificar ações de Práticas Avançadas de Enfermagem, como: habilidades avançadas de avaliação, julgamento, tomada de decisão e raciocínio diagnóstico, autoridade para diagnosticar, prescrever medicamentos, testes diagnósticos e tratamento terapêutico. No entanto, as evidências registradas no domínio Preparação Educacional denotam clara fragilidade pela inexpressiva frequência de enfermeiros credenciados com mestrado profissional. Conclusões: o estudo demonstra que enfermeiros do contexto estudado desenvolvem ações de prática avançada carecendo de mestrado profissional recomendado para credenciamento, com legislação pertinente, demandando iniciativas por parte das lideranças da enfermagem para superar esse desafio. Descritores: Enfermagem de Prática Avançada; Atenção Primária à Saúde; Estratégia Saúde da Família; Enfermagem; Ensino de Enfermagem.

\section{RESUMEN}

Objetivos: mapear acciones de Prácticas Avanzadas de Enfermería implementadas en Estrategia Salud de la Familia. Métodos: estudio transversal, exploratorio, realizado con enfermeros actuantes en Estrategia Salud de la Familia. Los datos obtenidos fueron comparados con las características definitorias del Enfermero de Prácticas Avanzadas adoptadas internacionalmente, mediante checklist elaborado sobre referencia de directrices del International Council of Nurses. Resultados: el mapeo permitió identificar acciones de Prácticas Avanzadas de Enfermería como: habilidades avanzadas de evaluación, juicio, toma de decisiones, razonamiento diagnóstico, autoridad para diagnosticar, prescribir medicamentos, test, diagnósticos y tratamiento terapéutico. Sin embargo, las evidencias registradas en el dominio preparación educacional marcan clara debilidad, por la carencia notable de enfermeros con maestrías cursadas. Conclusiones: el estudio demuestra que los enfermeros del ámbito estudiado desarrollan acciones de práctica avanzada careciendo de cursado de maestría recomendado para acreditación, con legislación pertinente, demandándose iniciativas de los líderes del área para superar dicho desafío. Descriptores: Enfermería de Práctica Avanzada; Atención Primaria de Salud; Estrategia de Salud Familiar; Enfermería; Educación en Enfermería. 


\section{INTRODUCTION}

The Member States of the Pan American Health Association (PAHO), gathered in Washington in 2014, deliberated in favor of adopting important strategies to implement the Universal Health Access and Universal Health Coverage policy recommended by the World Health Organization (WHO). That event allowed to observe the ongoing contribution and the potential progress of primary healthcare nursing in the development of advanced practices, so positive results in health promotion and disease prevention and recovery in less developed places were achieved ${ }^{(1)}$.

The International Council of Nurses (ICN) defined the advanced practice nurse as a professional who is registered to a recognized institution and obeys legislation that supports advanced practices to guarantee that this professional puts into practice complex clinical skills, carries out diagnoses, prescribes medications and tests, makes decisions, and has professional autonomy and leadership. According to the ICN Guidelines, nurses must have a master's degree to carry out these activities ${ }^{(2)}$.

The $52^{\text {nd }}$ PAHO Directing Council approved Resolution DC52. R13, entitled "Human Resources for Health: Increasing Access to Qualified Health Workers in Primary Health Care-Based Health Systems"(3). In response to this resolution, the PAHO nursing regional adviser began mobilizing leaders toward the goal, scheduling meetings aiming to plan action strategies oriented toward optimizing training of nurses for primary health care in the pan American region. The first Summit was organized by McMaster University and its Collaborating Centre and occurred from April 15 to 17, 2015 in Hamilton, Canada. In this event, invited leaders from several countries established five priorities to incorporate advanced practice nursing (APN): developing professional master's programs focused on APN; engaging leaders responsible for making decisions; mobilizing services capable of applying advanced and nursing practices to vulnerable and unassisted populations; creating a Pan American network whose goal is implementing APN in countries in the region not yet covered by this resource; and creating and implementing complementary functions in additional primary healthcare models, according to the context of each country ${ }^{(4)}$.

With an approach focused on Latin America, in 2016 a new PAHO strategical meeting on APN was held in the University of Michigan. In this event, nine competencies that characterize advanced practice nurses were outlined: clinical expertise, leadership, patient care expertise (individual, family, group, community, population), care and education of patient/family/healthcare providers, applied research, intra- and interprofessional collaboration, ethical decision-making, advocacy, and technology ${ }^{(5)}$.

As a consequence of these initiatives, the Brazilian National Nursing Council established the Commission of Advanced Practices in Nursing by means of Ordinance no. 379 of March 11, 2016 ${ }^{(6)}$.

In 2017, the Brazilian Ministry of Health regulated, by means of Ordinance no. 2,436, of September 21, 2017, the practices of nurses in the context of the Family Health Strategy (FHS) - Primary Health Care. These practices include health activities for users and families, home visits, and visits to community spaces; nursing appointments, execution of nursing procedures, and prescription of tests and medications according to municipal protocols and clinical and therapeutic guidelines; qualified listening, risk classification, risk stratification, design of care plans, referral to other services, nursing management, supervision, and specific assignments following the professional legislation ${ }^{(6)}$. Although the object of the mentioned ministerial ordinance did not refer to APN specifically, it is understood that there is a certain level of interface with the purpose shared by ICN and WHO/PAHO regarding adoption and implementation of APN by countries.

Therefore, APN is an extended area of the professional practice sphere that reflects integration and transfer of knowledge into interventions that result in health care for individuals, families and/or communities under the responsibility of a registered nurse. To develop activities in this area, nurses obtain a title after completing specialized training to develop clinical competencies, skills, and decision-making abilities to carry out APN actions.

Strategies to implement APN in Latin America and the Caribbean focused on primary health care can be structured according to the individual characteristics of each country. Brazil and Chile are two countries with nursing master's programs showing great potential for APN implementation ${ }^{(7)}$.

The present study was carried out to examine the adoption of this strategy in Brazil, focusing on the FHS context found in a municipality located in the north of the Brazilian state of Minas Gerais.

\section{OBJECTIVES}

To map APN actions implemented in the FHS context.

\section{METHODS}

\section{Ethical aspects}

The study proposal was approved by the Research Ethics Committee of the Ribeirão Preto College of Nursing at the University of São Paulo. Ethical principles of human research were observed, following Brazilian National Health Council Resolution no. $466 / 2012^{(8)}$. Free and informed consent forms were attached to the e-mails sent during the participant recruitment process.

\section{Study design and context}

This was a cross-sectional exploratory study carried out with nurses working in the FHS network in a municipality located in the north of the Brazilian state of Minas Gerais between April and May 2020.

According to data from the Brazilian National Register of Health Facilities of the Ministry of Health accessed in January 2021, this municipality has 771 low, intermediate, and high-complexity health facilities, of which $88(11 \%)$ are health centers/basic units, which are part of primary health care ${ }^{(9)}$. Data from the Brazilian Institute of Geography and Statistics released in 2020 showed that the municipality had a population of 413,487 people ${ }^{(10)}$.

Nurses were recruited by e-mail and received a message containing the study presentation, an invitation to participate voluntarily, and a link to record their acceptance and complete the data collection form, available in Google Forms. The professionals' 
e-mails were provided by the Primary Healthcare Coordinating Body at the Municipal Health Secretariat. Each nurse received the invitation to participate three times over the data collection period.

\section{Participants}

The municipality was chosen considering the FHS full coverage. Convenience sampling was carried out, and all nurses who worked in the FHS in the municipality (136) were considered eligible ${ }^{(11)}$.

It is important to stress that the municipality applies nursing care protocols that allow nurses to develop their activities in healthcare programs oriented toward children, women, and people with high blood pressure, diabetes, leprosy, tuberculosis, obesity, and skin injuries. In the two first cases, there are specific actions related to early detection and treatment of several diseases, pharmacological and non-pharmacological therapeutic description, and follow-up of users during treatment and after discharge ${ }^{(12)}$.

\section{Data source}

The used questionnaire was designed for the present study and had its face and content reviewed by a group of five nurses who worked as researchers and had attested experience in primary healthcare assistance and management and teaching in the nursing area. The instrument had 69 questions distributed over five domains: FHS identification; organization, and management; principles and guidelines of the Brazilian Unified Health System (SUS, as per its acronym in Portuguese); functions, actions, and skills developed in FHS; and knowledge of nurses regarding the digital technologies made available by SUS. In the first domain, the nurses informed personal characteristics (date of birth, gender, and level of education). In the others, nurses were asked to indicate the activities that were developed in the professional work sphere according to the nursing care protocols established by the municipality and Ordinance no. 2,436, of September 21, 2017 , on nursing practices in the primary healthcare context ${ }^{(6)}$.
The obtained data were compared to the characteristics expected for advanced practice nurses, and allowed to identify whether the participants (FHS nurses who worked in a municipality in the north of Minas Gerais) showed the necessary attributes. For this analysis, the researchers used a checklist whose design was based on 21 out of the 22 characteristics established in the ICN Guidelines for advanced practice nurses. One of the characteristics was excluded because it was not compatible with the work reality of nurses in Brazil and taking into account the argument ${ }^{(2)}$ that, although this characteristic is present in the ICN guidelines, no evidence was found supporting this requirement in some countries ${ }^{(2)}$. Therefore, the 21 characteristics were shown distributed over the three domains established in the Guidelines: educational preparation, nature of practice, and regulatory mechanisms - country-specific professional regulation and policies underpinning APN practice.

\section{Results analysis and statistics}

After collection, data were transferred to an Excel spreadsheet, and variables were analyzed according to descriptive statistics (frequency and percentage) using the SPSS software, version 25.0. The Guidelines on Advanced Practice Nursing, established by ICN, were used to examine advanced practice nursing ${ }^{(2)}$.

\section{RESULTS}

Thirty-nine nurses participated in the study, of whom $82 \%$ were women. The participants' age ranged from 24 to 50 years. The results were organized into three domains, according to the ICN Guidelines ${ }^{(2)}$.

Regarding alignment of the study participants with the characteristics that define advanced practice nurses, 11 attributes (52.4\%) were identified over the three domains (Table 1).

Table 2 shows the distribution of answers of the participants regarding the characteristics that define advanced practice nurses according to ICN in the educational preparation domain.

Table 1 - Characteristics $(n=21)$ that define advanced practice nurses according to the International Council of Nurses that were found in Family Health Strategy nurses who worked in a municipality in the north region of the Brazilian state of Minas Gerais, 2020

\begin{tabular}{|c|c|c|}
\hline Characteristics of the domains & $\mathbf{n}$ & $\%$ \\
\hline Educational preparation & 1 & 4.8 \\
\hline $\begin{array}{l}\text { 1. Educational preparation beyond that of a generalist or specialized nurse education at a minimum requirement of a full master's } \\
\text { degree programme (master's level modules taken as detached courses do not meet this requirement)* }\end{array}$ & Yes & \\
\hline $\begin{array}{l}\text { 2. Formal recognition of educational programmes preparing nurses specifically for advanced practice nursing (e.g. accreditation, } \\
\text { approval, or authorization by governmental or nongovernmental agencies)** }\end{array}$ & No & \\
\hline 3. A formal system of credentialing linked to defined educational qualifications & No & \\
\hline Nature of practice & 6 & 28.6 \\
\hline $\begin{array}{l}\text { 4. A designated role or level of nursing that has its focus on the provision of care, illness prevention and cure based on direct } \\
\text { and indirect healthcare services at an advanced level, including rehabilitative care and chronic disease management. This is } \\
\text { beyond the scope of practice of a generalist or specialized nurse. }\end{array}$ & Yes & \\
\hline $\begin{array}{l}\text { 5. The capability to manage full episodes of care and complex healthcare problems including hard to reach, vulnerable and } \\
\text { at-risk populations }\end{array}$ & No & \\
\hline 6. The ability to integrate research (evidence informed practice), education, leadership, and clinical management & Yes & \\
\hline 7. Extended and broader range of autonomy (varies by country context and clinical setting) & No & \\
\hline 8. Case-management (manages own case load at an advanced level) & Yes & \\
\hline 9. Advanced assessment, judgement, decision-making and diagnostic reasoning skills & Yes & \\
\hline 10. Recognized advanced clinical competencies, beyond the competencies of a generalist or specialized nurse & No & \\
\hline
\end{tabular}


11. The ability to provide support and/or consultant services to other healthcare professionals emphasizing professional collaboration

No

12. Plans, coordinates, implements and evaluates actions to enhance healthcare services at an advanced level

Yes

13. Recognized first point of contact for clients and families (commonly, but not exclusively, in primary healthcare settings)

Advanced practice nursing practice

14. Authority to diagnose

Yes

15. Authority to prescribe medications

Yes

16. Authority to order diagnostic testing and therapeutic treatments

Yes

17. Authority to refer clients/patients to other services and/or professionals

Yes

18. Authority to admit and discharge clients/patients to hospital and other services

No

19. Officially recognized title(s) for nurses working as advanced practice nurses

No

20. Legislation to confer and protect the title(s) (e.g. clinical nurse specialist, nurse practitioner)

No

21. Legislation and policies from an authoritative entity or some form of regulatory mechanism explicit to advanced practice

No

Source: Guidelines on Advanced Practice Nursing, International Council of Nurses, 2020.

Note: *It is recognized that, for some countries, the requirement of a master's degree may be an aspirational target while they make efforts to reach this standard. Intermediate programs and courses can be defined that may evolve into this standard; **Although some countries require clinical experience for nurses to enter an advanced practice nursing educational program, no evidence supporting this requirement was found.

Table 2 - Educational preparation of nurses $(n=39)$ who developed their activities in Family Health Strategy in a municipality located in the north of Minas Gerais, considering the characteristics that define advanced practice nurses according to the International Council of Nurses, 2020

\begin{tabular}{lcc}
\hline Level of education/type & $\mathbf{n}$ & $\%$ \\
\hline Professional master's degree & 2 & 5.1 \\
Academic master's degree & 2 & 5.1 \\
Residence & 5 & 12.8 \\
Lato Sensu specialization & & \\
$\quad$ Family health & 28 & 70 \\
Urgency and emergency & 8 & 17.5 \\
Occupational nursing & 1 & 2.5 \\
Public health & 2 & 5 \\
\hline
\end{tabular}

In the nature of practice domain, the results showed the connections between the actions developed by these professionals and the demands indicated by ICN regarding APN (Table 3). Nineteen (47.5\%) nurses mentioned an interval from one to five years in the item time working in the area, 16 (40\%) cited an interval from six to 10 years, and five (12.5\%) informed that they had been working in the area for over 10 years.
Table 4 shows the distribution of answers given by the participants regarding the APN practice domain of the characteristics that define advanced practice nurses according to ICN.

\section{DISCUSSION}

According to ICN and PAHO premises adopted by leaders who attended the two meetings held in Canada ${ }^{(4)}$ and the United States ${ }^{(5)}$, the first requirement for APN practice is having a professional master's degree in this area. In these two countries, APN is developed in accordance with all recommended criteria. In the present study, only four participants had a master's degree, with two degrees being academic and two professional.

The lack of professional master's degrees in APN characterizes the Brazilian reality, and not only the interior of the state, where the study was developed. A professional master's course in APN was established in Brazil only recently, with the proposal of beginning its activities in the women's health field ${ }^{(13)}$. Although this proposal was not implemented yet ${ }^{(14-15)}$, it provides for creation of courses in other areas in the future.

Table 3 - Nature of practice of nurses $(n=39)$ who developed their activities in Family Health Strategy in a municipality located in the north of Minas Gerais, 2020

\begin{tabular}{|c|c|c|c|}
\hline Variables & $\begin{array}{c}\text { Yes } \\
\text { n (\%) }\end{array}$ & $\begin{array}{c}\text { No } \\
n(\%)\end{array}$ & $\begin{array}{c}\text { No answer } \\
\text { n (\%) }\end{array}$ \\
\hline Reception of patients without an appointment in FHS & $38(97.4)$ & - & $1(2.6)$ \\
\hline Chronic disease risk stratification & 37 (94.9) & $1(2.6)$ & $1(2.6)$ \\
\hline Health education activities & 37 (94.9) & $1(2.6)$ & $1(2.6)$ \\
\hline Care plan formulation & $34(87.2)$ & $2(5.1)$ & $3(7.7)$ \\
\hline Home visit & $38(97.4)$ & - & $1(2.6)$ \\
\hline Visit to community spaces & $35(89.7)$ & $2(5.1)$ & $2(5.1)$ \\
\hline Care plan development & $31(79.5)$ & $7(17.9)$ & $1(2.6)$ \\
\hline Nursing process development & $32(82.1)$ & $6(15.4)$ & $1(2.6)$ \\
\hline Nursing history & $35(89.7)$ & $3(7.7)$ & $1(2.6)$ \\
\hline Nursing care plan and prescription & $34(87.2)$ & $4(10.3)$ & $1(2.6)$ \\
\hline Nursing evolution & $38(97.4)$ & - & $1(2.6)$ \\
\hline Knows the mobile technologies of the Ministry of Health & $24(61.5)$ & $14(35.9)$ & $1(2.6)$ \\
\hline Uses technology to facilitate communication with FHS users & $9(23.1 \%)$ & $29(74.4)$ & $1(2.6)$ \\
\hline
\end{tabular}

Note: FHS - Family Health Strategy. 
Table 4 - Advanced practice nursing practice of nurses $(n=39)$ who developed their activities in Family Health Strategy in a municipality located in the north of Minas Gerais, 2020

\begin{tabular}{|c|c|c|c|}
\hline Variables & $\begin{array}{c}\text { Yes } \\
\text { n (\%) }\end{array}$ & $\begin{array}{c}\text { No } \\
\text { n (\%) }\end{array}$ & $\begin{array}{c}\text { No answer } \\
n(\%)\end{array}$ \\
\hline Executes nursing appointments\# & $37(94.9)$ & $1(2.6)$ & $1(2.6)$ \\
\hline Executes nursing procedures* & $37(94.9)$ & - & $2(5.1)$ \\
\hline Requests tests*** & $38(97.4)$ & - & $1(2.6)$ \\
\hline Prescribes medications according to municipal decree $* * *$ & $38(97.4)$ & - & $1(2.6)$ \\
\hline Fulfills therapeutic guidelines according to municipal protocol & $36(92.3)$ & $2(5.1)$ & $1(2.6)$ \\
\hline Refers to other services & $37(94.9)$ & $1(2.6)$ & $1(2.6)$ \\
\hline Carries out nursing prognosis & $27(69.2)$ & $11(28.2)$ & $1(2.6)$ \\
\hline Carries out nursing diagnosis & $28(71.8)$ & $10(25.6)$ & $1(2.6)$ \\
\hline
\end{tabular}

Note: \#prevention, appointments for children, elderly people, people with diabetes, people with hypertension, appointments to address problems related to mental health, tuberculosis, sexually transmitted infections, leprosy, appointments for pregnant women, postpartum women, adolescents, and to offer prenatal care, appointments to address questions related to sexual orientation, preventive cervical screening, family planning, evaluation of pressure injuries, integrated management of childhood illnesses, encouragement to reduction of harm caused by tobacco (all authorized by the municipality protocol); *blood pressure measurement, dressings, capillary glycemia measurements, collection of material for preventive cervical screening, indwelling urinary catheter insertion, medication administration, newborn blood spot test, stitch removal, anthropometry, rapid molecular test for tuberculosis, foreign body removal, change of indwelling and intermittent urinary catheter, monofilament testing (diabetic foot), auriculotherapy, rehydration, inhalation, administration of vitamin A, change of colostomy bag, vaccination, ear cleaning, neonatal screening, rapid test for sexually transmitted infections (all authorized by the municipality protocol); ** Cytopathological clinical analysis, screening mammography, prenatal specific tests, women's health, 1st and 3rd pregnancy trimester testing, systemic arterial hypertension, blood count, fasting glycemia, glycemia 2 hours after administration of $75 \mathrm{~g}$ of dextrose, venereal disease research laboratory, HIV testing, HBsAg testing, urine culture, antibiogram, toxoplasmosis serology, laboratory and imaging testing, blood, stool, and urine testing, and obstetric ultrasound (all authorized by the municipality protocol); ***folic acid, ferrous sulfate, nystatin, miconazole, fluconazole, paracetamol, antibiotics, painkillers, vaginal ointments, anti-inflamatories, syrups, contraceptive medications, dipyrone, scopolamine, metoclopramide, Noripurum, betamethasone, ceftriaxone, diclofenac-dexamethasone, Citoneurin, vermifuges, medications to treat sexually transmitted infections and tuberculosis, antihypertensives, hypoglycemics, supplements, and medications listed in the municipality nursing protocol.

Incorporating the APN concept and making the collective commitment to PAHO of creating professional master's programs focused on APN are still incipient initiatives, especially if it is considered that this commitment has to be compatible with the characteristics of the profession in a country with 1,236 face-to-face nursing undergraduate schools/courses, both public and private ${ }^{(16)} ; 22$ professional master's programs, 53 academic master's courses, two professional

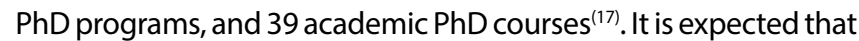
institutions with a critical mass capable of putting into practice these courses successfully have an annual number of graduates who can go back to their origin institutions with the purpose of gathering entrepreneurial leaders and promote alliances oriented toward creating professional master's programs, especially in APN. These alliances may be established with the institutions that already are responsible for graduate courses/programs with a reputable history of academic productivity and capacity to expand their range of course offer, including a professional master's in APN. This is a challenge posed to nursing in several countries, and the authors of the present study believe that the current level of development of Brazil favors the necessary engagement. Brazilian nursing has 839 research groups registered in the National Council for Scientific and Technological Development Directory of Research Groups ${ }^{(18)}$, of which scientific productivity and training of human resources for research are expected. With this human resource scenario, it is presumed that there will be skills and innovation, with changes in health services to be introduced, and professional master's courses are the appropriate mechanism to achieve that.

Despite the needs exposed above, it was found that educational preparation was the domain that showed the greatest fragilities regarding recognition and credentialing of advanced practice nurses. However, according to the nature of practice domain, nurses have skills to make decisions and autonomy to prescribe medications and make nursing diagnosis, which were seen as positive points for implementing advanced practices. In this context, it is pertinent to emphasize the knowledge management capable of establishing solid connections between explicit and tacit knowledge, as well as the different modalities of knowledge transfer, aiming to increase the quality of training of nurses regarding advanced practices by means of specialized knowledge translated as excellence with autonomy.

Institutional or group positions begin to emerge, whether in support of short-term courses to specialize nurses in APN ${ }^{(19)}$ or to advocate that higher education institutions reformulate their curricula and that legislation that acknowledges and guarantees teaching of APN is implemented ${ }^{(20-21)}$. Consensuses have been reached in favor of incorporation of professional master's programs in nursing focusing on advanced practices to scientifically prepare nurses, so they carry out their clinical and management practice with proficiency to lead with autonomy and evidencebased decision-making capacity $y^{(13,22)}$.

A study on the perception of alumni of nursing residence courses and professional master's programs in APN in primary health care showed that the participants' evaluation of the interaction between these two types of training was positive, because it made nurses develop advanced practices and greater autonomy ${ }^{(23)}$.

A large-scale study in WHO Western Pacific region involving 37 countries examined the responsibilities of nurses that occupy advanced functions as a strategy for equitable access to health care. It was found that these advanced functions were not limited to clinical activities in hospital settings, since the professionals actively participated in actions linked to primary health care, teaching, leadership, and quality and research management ${ }^{(24)}$. This study illustrated the range of possibilities of focus of professional master's programs, which can be chosen according to local and regional characteristics. Countries in Latin America and the Caribbean are in a situation that favors adoption of APN to improve health results regarding the development of this nursing field, but they depend on the union of leaders of different nursing sectors so they can make progress in the negotiation with other sectoral leaders ${ }^{(25-28)}$. These are the current challenges of Brazilian nursing: establishing internal harmonization, converging and unifying leaderships, and implementing regulation systems and policies that support the necessary practice. In a posterior step, it will be necessary to promote coordination with ministries and forces of other health professions to achieve agreement and implementation. Meanwhile, advanced sectors in the education 
sphere should prepare human resources at the level of professional master's in APN to supply the job market.

Additionally, there is the need for negotiation in the context of the Ministry of Health to guarantee that nurses are allowed to develop comprehensive work in nursing care based on their professional training so they can contribute even more to the fulfillment of health policies ${ }^{(29)}$.

Legislative bodies, together with educational institutions, have the responsibility of investing in the educational preparation of nursing professionals who work in FHS and providing credentialing and recognition of their practices. It is urgent that action initiatives be taken and that change triggers be mobilized in several instances.

To bridge the gap regarding professional training specific for APN according to the ICN principles and taking into account nurses' skills, the weaknesses found in the present study can be fixed with strategies and policies by governments and educational institutions. In addition, nurses must be encouraged to invest in their own professional development through continuing education.

It is also necessary that our initiatives mirror examples of progress already consolidated worldwide, especially in developed countries, where difficulties similar to those Brazil is currently facing were already overcome and APN is implemented and expanding, as pointed out by the literature that reports challenges, tendencies, implications, opportunities, and results in health services ${ }^{(30-32)}$. Leaders of international organizations urge all stakeholders to optimize efforts, contributions, political will, financial resources, and strategies to promote the nursing and obstetrics work force and every sphere to do their part, protecting, investing, and putting initiatives together, so the necessary investments in education in nursing are sped up $^{(33)}$.

\section{Study limitations}

The lack of specific legislation in Brazil for the practice of APN is a hindering factor for the establishment of limits for the actions developed by the participants of the present study based on the ICN Guidelines. The APN characteristics absent in the present study show the path that has to be taken by Brazilian nursing to align the training of advanced practice nurses with international guidelines.

\section{Contributions to the nursing area}

The present study contributed to reinforcing the need to establish a policy supporting the implementation of APN in Brazil and advocated investments in professional master's programs in this specialty, legislation addressing these practices, and their credentialing in the country.

\section{CONCLUSIONS}

Mapping APN actions in the FHS context in a municipality in the north region of the Brazilian state of Minas Gerais showed that nursing professionals who worked in this sphere of primary health care had the necessary knowledge, attitudes, and skills to prescribe medications and tests. Additionally, they had autonomy when carrying out nursing diagnoses, receiving patients in the units, and executing nursing procedures, in accordance with nursing care protocols established in the context in which they were inserted. However, evidence gathered for the educational preparation domain exposed patent fragility, expressed as a reduced percentage of nurses with a professional master's degree in this specialty, a requirement mentioned in the ICN Guidelines. For the challenge of implementing APN to be properly tackled, this result has to draw the attention of legislative bodies and institutions that prepare human resources in nursing.

\section{FUNDING}

This study was financed in part by the Coordenação de Aperfeiçoamento de Pessoal de Nível Superior-Brasil (CAPES) - Finance Code 001.

\section{REFERENCES}

1. Organização Pan-Americana da Saúde (OPAS). Ampliação do papel dos enfermeiros na atenção primária à saúde. Washington, D.C: OPAS; 2018.

2. Schober M, Lehwaldt D, Rogers M, Steinke M, Turale S. Pulcini J, et al. Guidelines on advanced practice nursing [Internet]. Geneva: International Council of Nurses. 2020[cited 2021 Mar 20]. 44p. Available from: https://www.icn.ch/system/files/documents/2020-04/ICN APN\%20Report_EN_WEB.pdf

3. Organização Pan-Americana da Saúde (OPAS). Organização Mundial da Saúde (OMS). 52o Conselho Diretor 65a Sessão do Comitê Regional Washington, D.C., EUA, 30 de setembro a 4 de outubro de 2013.

4. McMaster University. Cúpula de Enfermeiros de Prática Avançada da OPAS. Hamilton, Canadá 15 a 17 de Abril de 2015. 37p.

5. University Michigan School of Nursing. PAHO Advanced Practice Nursing Summit 2016.1 Advanced Practice Nursing Summit: developing advanced practice nursing competencies in Latin America to contribute to universal health. Ann Arbor, Michigan, April 7-9, 2016.27p.

6. Conselho Federal de Enfermagem (COFEn). Comissão de Práticas avançadas em Enfermagem [Internet]. 2017[cited 2021 Mar 20]. Available from: http://www.cofen.gov.br/wp-content/uploads/2017/04/Apresenta\%C3\%A7\%C3\%A3o-_-Leonardo-e-Edson.pdf

7. Oldenburger D, Cassiani SHB, Bryant-Lukosius D, Valaitis RK, Baumann A, Pulcini J, et al. Estratégia de implementação para prática avançada de enfermagem na atenção primária à saúde na América Latina e no Caribe. Rev Panam Salud Publica [Internet]. 2017[cited 2021 Mar 20];41:e40. Available from: http://www.scielosp.org/pdf/rpsp/v41/1020-4989-RPSP-41-e40.pdf

8. Ministério da Saúde (BR). Conselho Nacional de Saúde (CNS). Resolução 466/12. Trata de pesquisas envolvendo seres humanos e atualiza a resolução 196[Internet]. Diário Oficial da União. 12 dez. 2012 [cited 2021 Mar 20]. Available from: http://conselho.saude.gov.br/resolucoes/2012/Reso466.pdf 
9. Instituto Brasileiro de Geografia e Estatística (IBGE). Montes Claros. Cidades e Estados: população estimada [Internet]. 2020. [cited 2021 Mar 20] Available from: https://www.ibge.gov.br/cidades-e-estados/mg/montes-claros.html

10. Ministério da Saúde (BR). Cadastro Nacional de Estabelecimentos de Saúde (CNES). Consulta Estabelecimento: identificação [Internet]. 2021 [cited 2021 Mar 20] Available from: http://cnes.datasus.gov.br/pages/estabelecimentos/consulta.jsp

11. Ministério da Saúde (BR). e-Gestor Atencao básica: 2021 [Internet]. 2021 [cited 2021 Mar 20] Available from: https://egestorab.saude.gov.br/ paginas/acessoPublico/relatorios/relHistoricoCoberturaAB.xhtml

12. Prefeitura Municipal de Montes Claros Protocolo. Guia rápido de orientação do protocolo assistencial de enfermagem do município de Montes Claros. 2018. p.33.

13. Mattos-Pimenta CA, Coca KP, Amorim MHC, Belasco AGS, Gabrielloni MC, Schirmer J. Prática Avançada em Enfermagem na Saúde da Mulher: formação em Mestrado Profissional. Acta Paul Enferm. 2020;33:eAPE20200123. https://doi.org/10.37689/actaape/2020AE01235

14. Ministério da Educação (BR). Capes. Plataforma Sucupira. Curso Avaliados e Reconhecidos. Dados Básicos do Programa: Unifesp [Internet]. 2021 [cited 2021 Mar 05]. Available from: https://sucupira.capes.gov.br/sucupira/public/consultas/coleta/programa/viewPrograma. jsf?popup=true\&cd_programa=33009015035P2

15. Universidade Federal de São Paulo (Unifesp). Escola Paulista de Enfermagem Programa de Pós-Graduação em Enfermagem [Internet]. 2021 [cited 2021 Mar 05]. Available from: http://ppg.enfermagem.sites.unifesp.br/

16. Ministério da Educação (BR). Cadastro Nacional de Cursos e Instituições de Educação Superior Cadastro e-MEC [Internet]. 2021 [cited 2021 Mar 05]. Available from: https://emec.mec.gov.br/emec/nova\#avancada

17. Ministério da Educação (BR). Capes. Cursos Avaliados e Reconhecidos [Internet]. 2021[cited 2021 Mar 05]. Available from: https://sucupira. capes.gov.br/sucupira/public/consultas/coleta/programa/quantitativos/quantitativoBuscaAvancada.jsf

18. Ministério da Educação (BR). CNPq. Diretório dos grupos de Pesquisa do Brasil Lattes [Internet]. 2021[cited 2021 Mar 05]. Available from: http://dgp.cnpq.br/dgp/faces/consulta/consulta_parametrizada.jsf

19. Toso BRGO. Práticas avançadas de enfermagem em Atenção Primária: estratégias para implantação no Brasil. Enferm Foco. 2016;7(3/4):3640. https://doi.org/10.21675/2357-707X.2016.v7.n3/4.913

20. Paz EPA, Cunha CLF, Menezes EA, Santos GL, Ramalho NM, Werner RCD. Práticas Avançadas em Enfermagem: rediscutindo a valorização do enfermeiro na Atenção Primária à Saúde. Enferm Foco. 2018;9(1):41-3. https://doi.org/10.21675/2357-707X.2018.v9.n1.1856

21. Miranda Neto MV, Rewa T, Leonello VM, Oliveira MAC. Advanced practice nursing: a possibility for Primary Health Care? Rev Bras Enferm. 2018;71(Supl 1):716-21. https://doi.org/10.1590/0034-7167-2017-0672

22. Padilha MI, Maliska IA, Costa R, Benedet SA, Gelbcke FL, Anders JC. Professional master program: preparing the nurse of the future. Rev Bras Enferm. 2020;73(Suppl 5):e20200007. https://doi.org/10.1590/0034-7167-2020-0007

23. Rewa T, Miranda Neto MV, Bonfim D, Leonello VM, Oliveira MA. Práticas Avançadas de Enfermagem: percepção de egressos da residência e do mestrado profissional. Acta Paul Enferm. 2019;32(3):254-60. https://doi.org/10.1590/1982-0194201900035

24. Kim S, Lee TW, Kim GS, Cho E, Jang W, Choi M, et al. Nurses in advanced roles as a strategy for equitable access to healthcare in the WHO Western Pacific region: a mixed methods study. Hum Resour Health. 2021;19(19). https://doi.org/10.1186/s12960-021-00555-6

25. Zug KE, Cassiani SHB, Pulcini J, Bassalobre Garcia A, Aguirre-Boza F, Park J. Advanced practice nursing in Latin America and the Caribbean: Regulation, education and practice. Rev. Latino-Am Enfermagem. 2016;24:e2807. https://doi.org/10.1590/1518- 8345.1615.2807

26. Bryant-Lukosius D, Valaitis R, Martin-Misener R, Donald F, Morán Peña L, Brousseau L. Advanced Practice Nursing: a strategy for achieving universal health coverage and universal access to health. Rev Latino-Am Enfermagem. 2017;25:e2826. https://doi.org/ $10.1590 / 1518-8345.1677 .2826$

27. Cassiani SH, Zug KE. The advanced practice nursing role in Latin America: challenges, opportunities and implications for universal health coverage. Investig Enferm: Imagen Desarrollo. 2015;17(1). https://doi. org/10.11144/Javeriana.IE17-1.apnr

28. Honig J, Lindrud SD, Dohrn J. Moving towards universal health coverage: advanced practice nurse competencies. Rev Latino-Am Enfermagem. 2019;27:e3132. https://doi.org/10.1590/1518-8345.2901.3132

29. Cassiani SHB, Rosales LK. Iniciativas para a Implementação da Prática Avançada em Enfermagem na Região das Américas. Esc Anna Nery. 2016;20(4):e20160081. https://doi.org/10.5935/1414-8145.20160081

30. Nardi DA, Diallo R. Global trends and issues in APN practice: engage in the change. J Prof Nurs. 2014;30(3):228-32. https://doi.org/10.1016/j. profnurs.2013.09.010

31. Sheer B, Wong FK. The development of advanced nursing practice globally. J Nurs Scholarsh. 2008;40(30):204-11. https://doi.org/10.1111/ j.1547-5069.2008.00242.x

32. King R, Tod A, Sanders T. Development and regulation of advanced nurse practitioners in the UK and internationally. Nurs Stand. 2017;32(14): 43-50. https://doi.org/10.7748/ns.2017.e10858

33. Buchan J, Campbell J, McCarthy C. Optimizing the contributions of nursing and midwifery workforces: \#Protect, \#Invest, \#Together. Hum Resour Health. 2021;19(26). https://doi.org/10.1186/s12960-021-00577-0 